\title{
(0) NNSA
}

\section{NATIONAL NUCLEAR SECURITY ADMINISTRATION Nonproliferation Graduate Fellowship Program}




\section{DISCLAIMER}

This report was prepared as an account of work sponsored by an agency of the United States Government. Neither the United States Government nor any agency thereof, nor Battelle Memorial Institute, nor any of their employees, makes any warranty, express or implied, or assumes any legal liability or responsibility for the accuracy, completeness, or usefulness of any information, apparatus, product, or process disclosed, or represents that its use would not infringe privately owned rights. Reference herein to any specific commercial product, process, or service by trade name, trademark, manufacturer, or otherwise does not necessarily constitute or imply its endorsement, recommendation, or favoring by the United States Government or any agency thereof, or Battelle Memorial Institute. The views and opinions of authors expressed herein do not necessarily state or reflect those of the United States Government or any agency thereof.

\section{PACIFIC NORTHWEST NATIONAL LABORATORY}

operated by

\section{BATTELLE}

for the

\section{UNITED STATES DEPARTMENT OF ENERGY}

under Contract DE-AC05-76RL01830 


\section{Contents}

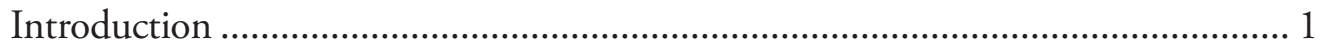

A Partial-year Report ............................................................................... 1

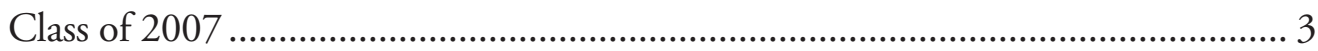

Roundtables .................................................................................................. 3

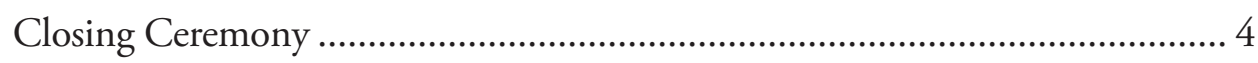

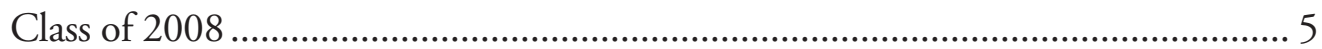

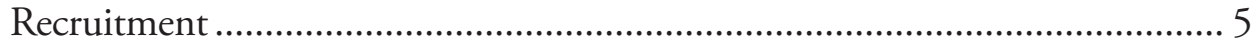

Interview Week ................................................................................... 6

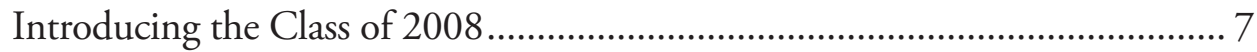

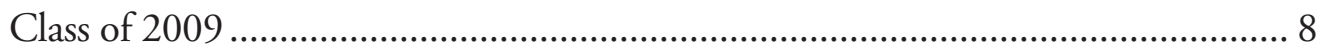

Recruitment Strategy ......................................................................... 8

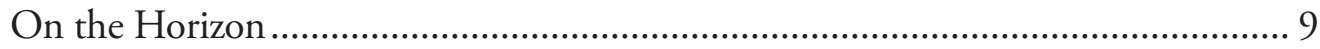

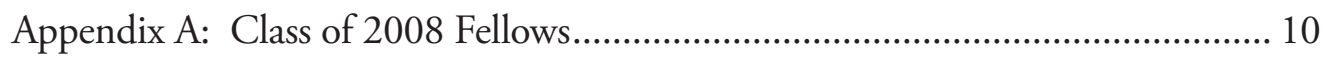




\section{Introduction}

In the 2007-2008 timeframe, the National Nuclear Security Administration (NNSA) Nonproliferation Graduate Fellowship Program (NGFP) continued building a solid foundation as the program began reaping the benefits of recently implemented changes. In the previous year, the Federal Program Manager, Phyllis Byrd, collaborated closely with the contractor, Pacific Northwest National Laboratory (PNNL), which had recently appointed Jana Fankhauser as the Program Manager. Through their partnership, the program was invigorated with fresh ideas and solutions, including improvements to the security clearance process, reengineering Orientation, improvements to the budget and funding model, and a more strategic approach to recruiting. As a result of those efforts, this year enjoyed several excellent outcomes.

- The program class size doubled from 11 Fellows in the Class of 2007 to 21 Fellows in the Class of 2008, a reflection of the Office of Defense Nuclear Nonproliferation (DNN) Program Offices' growing confidence in the NGFP.

- Recruitment results showed vast improvements; in addition to having a large pool of excellent candidates, there were several well-qualified candidates for each open position.

- Working in partnership with NA-22 to enhance and expand technical recruitment, the program increased contact with technical schools and had more technical candidates apply to the program.

- The NGFP program management conquered the legacy challenge of security clearances - and set a new record: $80 \%$ of the Fellows held clearances before their terms began in June, and 100\% had their security clearances granted by August.

- To enhance the program's assistance to Fellows in their career planning and search for post-program work, career development roundtables were added to the last quarter of the Fellowship Program.

\section{A Partial-year Report}

This abbreviated Annual Report covers program activities from October 2007 through May 2008the timeframe between the last Annual Report (which covered activities through September 2007) and the next report (which will begin with June 2008 activities). This shift in the Annual Report's timeframe will align it with the program's lifecycle, which begins and ends with the incoming and outgoing Fellowship classes in June.

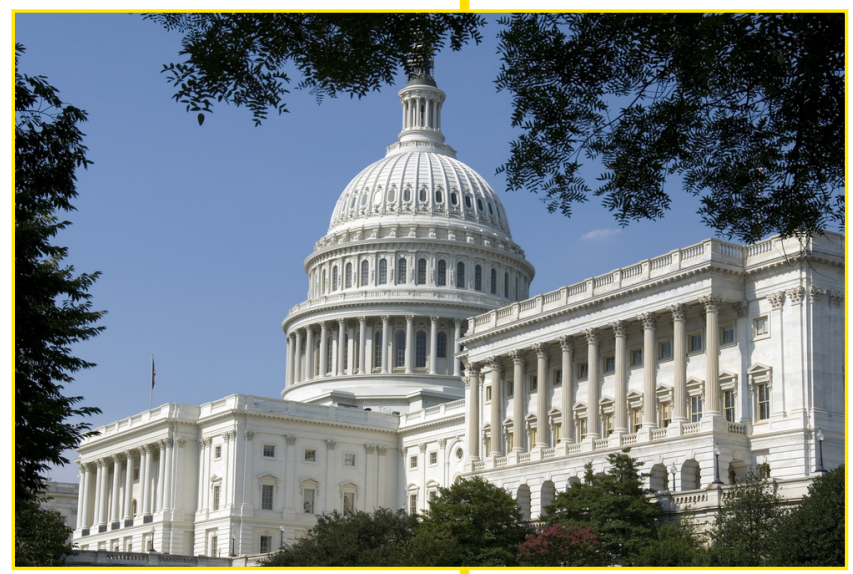

The NGP is a robust fellowship program that serves to expand the community of leaders for the nonproliferation and international security area. 


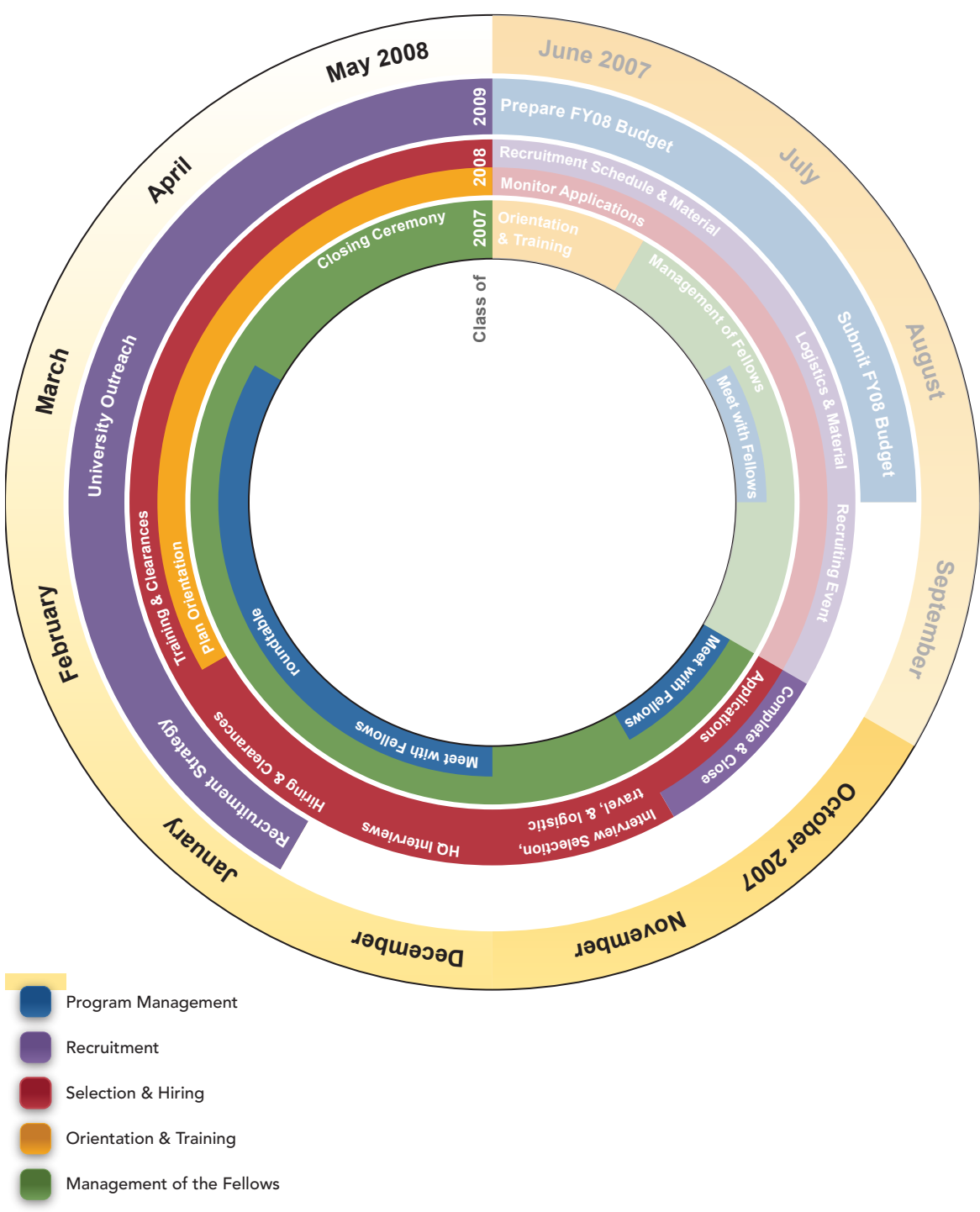

Program activities from October 2007 through May 2008 spanned three separate classes of Fellows: those hired in 2007, 2008, and 2009. (The NGFP classes are named for the year in which they are hired, not the year in which they graduate.) In this diagram, the type of activities are color-coded by program element.

This report is organized by Fellowship class and the pertinent program activities for each, including:

October 2007 Recruiting events and final applications (Class of 2008)

Winter 2007 Selection and hiring (Class of 2008)

Spring 2008 Career development roundtables (Class of 2007)

Orientation planning (Class of 2008)

Recruitment planning and university outreach (Class of 2009)

May 2008 Closing ceremony (Class of 2007) 


\section{Class of 2007}

The Class of 2007 Fellows began work in June 2007 and, by October, their work was in full swing. The Class of 2007 Fellows and the Program Offices they served were:

Georgia Adams, NA-20: The Office of Defense Nuclear Nonproliferation

Ethan Bodnaruk, NA-212: Office of European \& African Threat Reduction

Eric Brewer, NA-242: Global Security Engagement \& Cooperation, International Nuclear Export Control Program

Alex Christian, NA-242: Global Security Engagement \& Cooperation, Global Initiatives for Proliferation Prevention

John Creasy, NA-211: Office of North \& South American Threat Reduction

Lindsay Guthrie, NA-256: Office of Second Line of Defense \& Megaports Initiative

Erika Hunsicker, NA-255: Office of National Infrastructure and Sustainability

Sheng Li, NA-242: Global Security Engagement \& Cooperation, International Nuclear Safeguards and Engagement Program

Johnna Myers, NA-242: Global Security Engagement \& Cooperation, Global Initiatives for Proliferation Prevention

Courtney Stewart, NA-243: Office of International Regimes \& Agreements

Ryan Whalen, NA-242: Global Security Engagement \& Cooperation, International Nuclear Export Control Program

\section{Roundtables}

As they approach the last months of their Fellowships, the Fellows make plans for continuing their careers in nonproliferation. The NGFP supports these efforts in several ways - with resumes, job searches, contacts, and informational interviews and in 2007, an additional support mechanism was implemented. Roundtables were conducted with nonproliferation professionals from nonprofit, contractor, and government sectors, where Fellows could learn first-hand about their career paths and ask them questions.

The first roundtable took place in February and featured Sharon Squassoni of the Carnegie Endowment for International Peace; Elizabeth Turpen of the Stimson Center; and Laura Holgate of the Nuclear Threat Initiative. The event was very well received by the NGFP Fellows. The second roundtable was in April and featured several U.S. Department of Energy (DOE) national laboratory professionals, including Gordon Dudder of PNNL; Dr. Leslie Fishbone of Brookhaven National Laboratory; Dr. Kirsten Laurin-Kovitz of Argonne 
National Laboratory; Dr. Larry Satkowiak of Oak Ridge National Laboratory; and Dr. Jay Zucca of Lawrence Livermore National Laboratory. Each of the speakers provided a brief overview of their laboratory's work and mission focus, as well as the work their laboratory performs that specifically supports the NNSA's mission.

\section{Closing Ceremony}

The closing ceremony for the Class of 2007 took place on May 29, 2008. Speakers included Phyllis Byrd, the NGFP Federal Program Manger; William Tobey, the Deputy Administrator for DNN; and Steve Black, the Chief Operating Officer for DNN. Program Office Supervisors were also in attendance. Jana Fankhauser, Tami Weber, and Jessica Sandusky attended on behalf of PNNL. The Class of 2007 provided an overview of their projects and thanked their supervisors and the NGFP team for the opportunity and support.

Several graduates of the Class of 2007 continue to support the DNN, including the NA-21 Office of Threat Reduction and the NA-25 Material, Protection Control and Accounting Program. Others moved on to the Defense Intelligence Agency, the DOE Office of Intelligence, and Sandia National Laboratories; some returned to school to finish their graduate degrees.

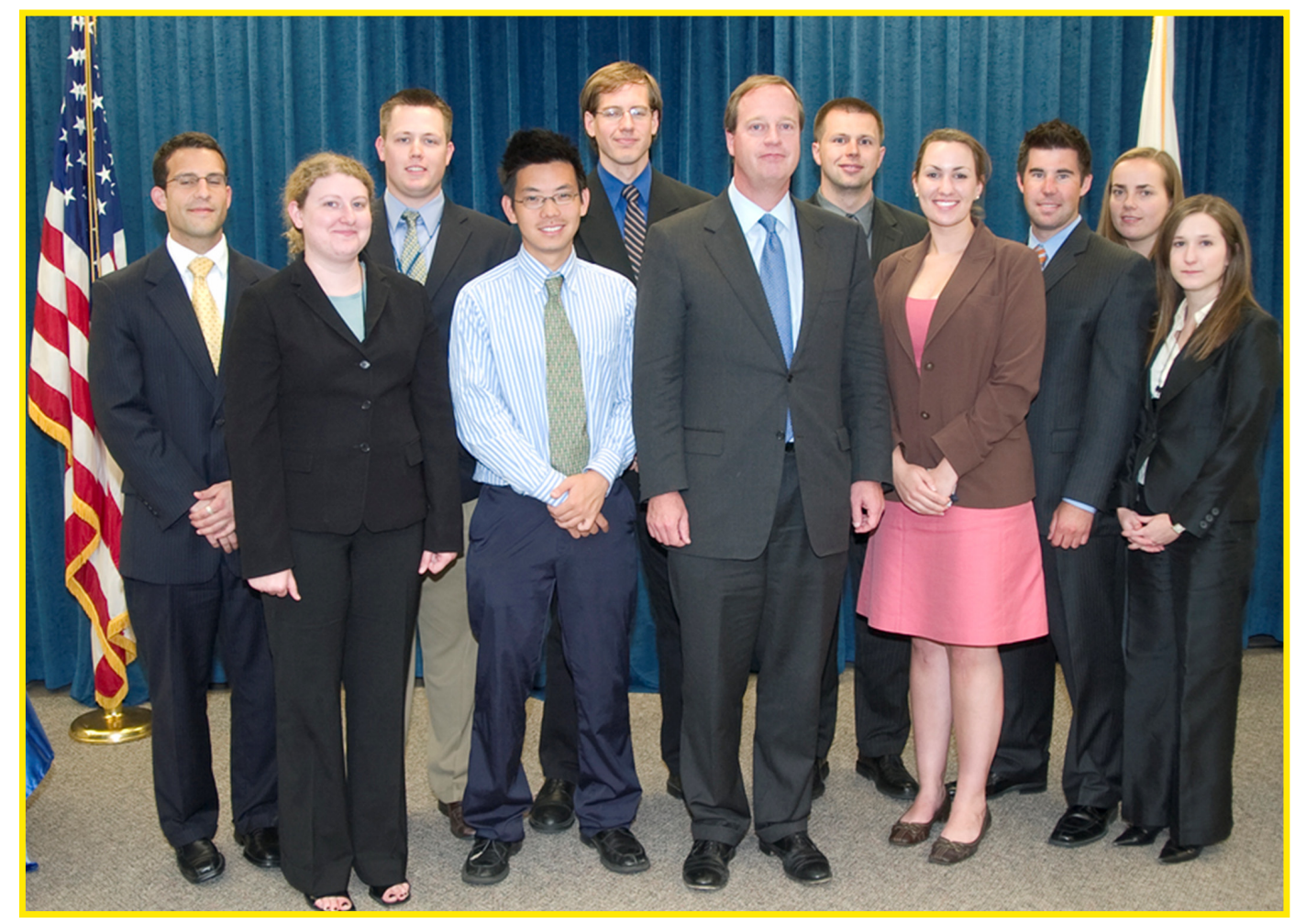

The Class of 2007 with the Deputy Administrator for DNN at the Closing Ceremony. (Left to Right: Ryan Whalen, Johnna Myers, Alex Christian, Sheng Li, Ethan Bodnaruk, William Tobey, John Creasy, Georgia Adams, Eric Brewer, Erika Hunsicker, and Courtney Stewart.) 


\section{Class of 2008}

\section{Recruitment}

The recruitment strategy implemented in 2007 focused on fewer universities that had a strong history of NGFP applicants. By focusing on fewer universities, and applying a discrete set of criteria to the selection of universities, recruitment resources were optimized while maintaining a large pool of applicants. In 2006, NGFP recruiters visited a total of 50 schools; in 2007, NGFP recruiters visited 19. Still, the application numbers were slightly higher for 2007, with a noticeable improvement in the quality of the candidates. The criteria-based approach implemented for 2007 selected schools that met at least two of the four criteria: 1) committed to diversity; 2) top nonproliferation/national security program; 3) top engineering school/physics/science program; 4) consistent participation from certain program/schools. In 2007, the NGFP made progress in building relationships with key associations, notably Women in International Security (WIIS) and the American Nuclear Society (ANS). Excellent outcomes resulted when the linkages were made. Other key tactics in 2007 included a focus on increasing technical candidates and implementing an online campaign.

On-campus recruiting began in September 2007 and shifted the focus from career fairs to smaller information sessions, specifically on nonproliferation and international security. Recruiting efforts included 25 information sessions/ colloquium seminars in a 35-day timeframe, from mid-September to mid-October.

- Campus program career fairs included Rice University, University of New Mexico, MIT, University of Maryland, University of Denver, Graduate School of International Studies (GSIS), and Johns Hopkins University SAIS.

- Information sessions were given at Syracuse University, Texas A\&M, George Washington University's Elliot School, Georgetown, American University, University of Washington, University of Michigan, University of California, Berkeley, Monterey Institute, Oregon State, Johns Hopkins University SAIS, Indiana University, George Mason, and Princeton.

In all, the on-campus career fairs and information sessions resulted in 71 applications and 19 hired Fellows. The remaining applicants and hires resulted from referrals by graduate department contacts, friends, the NGFP and university websites, campus graduate career centers, and NNSA contacts.

The 2007 recruitment strategy had several highlights:

- The quality of candidates was significantly greater than in past years, as well as the number of qualified candidates: for every strong candidate, there were four or five more that were equally qualified. Seven candidates had technical degrees in Physics, Security Engineering, Environmental Science, Radiation Health Physics, and two were Ph.D./Post-Doctoral Physics students. The remainder were pursing degrees in International Security, Applied Intelligence, U.S. 
Foreign Policy, Public Policy, Nuclear, Chemical, Biological Weapons Defense and Counterterrorism, Security Studies, Russian/Eastern European Studies, and Political Science.

- All of the candidates had more relevant experience than in previous years. For example, numerous candidates had previously interned or worked for federal agencies, including the State, Treasury, and Justice Departments.

- The strategy to target relevant academic departments and programs at universities across the country resulted in strong improvement in techniques for recruiting technical candidates.

- New online recruiting efforts were successfully developed and implemented.

In 2007, the NGFP received applications from 45 universities. The hired Class of 2008 represents 11 of those universities:

- University of Washington (4)

- Monterey Institute of International Studies (4)

- American University (3)

- University of Denver, GSIS (3)

- Johns Hopkins University, SAIS (1)

- George Washington University (1)

- George Mason University (1)

- Georgetown University (1)

- Indiana University, Bloomington (1)

- University of Michigan (1)

- Oregon State University (1)

\section{Interview Week}

Interview week at Headquarters was a resounding success. The Federal Program Manager engaged a team of three (the PNNL Program Manager, Operations Manager, and Recruitment Coordinator) to facilitate the week, with additional support from the PNNL Administrator, who organized all logistical support for the week. The number of candidates selected for interviews was nearly twice the number from the previous year, and the number of actual interviews jumped from 60 in 2006 to over 100 interviews in 2007, many of which were arranged on-thefly as the week progressed.

Outstanding feedback was received from the DNN Program Offices for the smooth execution of the notoriously hectic week, and they were especially impressed by the quality of the candidates. In fact, the class size doubled: 21 Fellows were hired for the Class of 2008, compared to 11 Fellows hired in 2007. In response to this increase in class size, the NGFP program management designed a Skills Questionnaire for the Program Offices to complete before the next fall recruitment timeframe, to know the skills and numbers of candidates needed. 


\section{Introducing the Class of 2008}

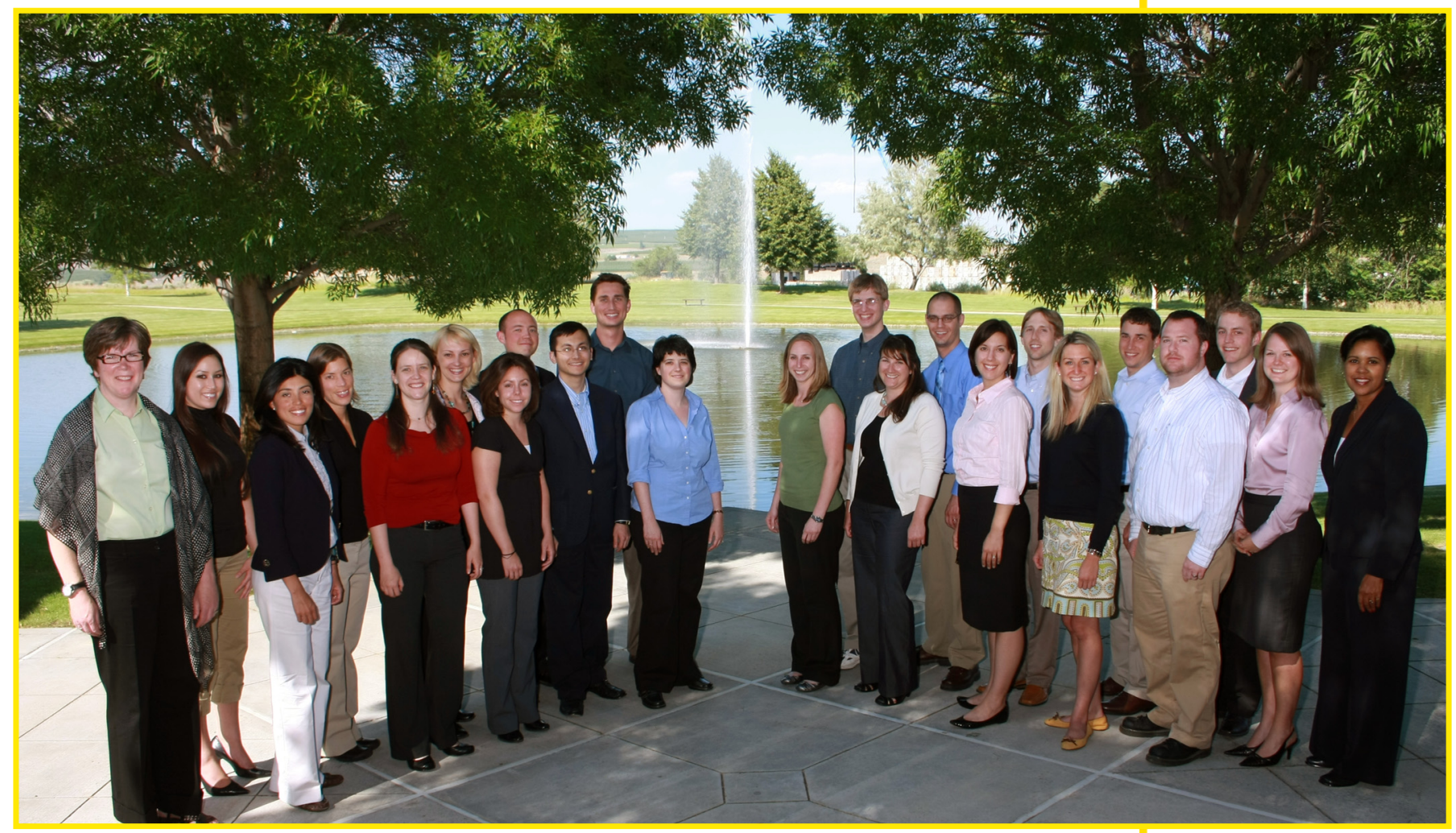

Pictured here are the Class of 2008 with the Federal Program Manager, Phyllis Byrd, on the far right, and the PNNL Program Manager, Jana Fankhauser, on the far left. From left to right, the Fellows and their assigned Program Offices are: Kristen Lau, NA-242: International Nuclear Safeguards and Engagement Program; Kathia Niewiadomski, NA-26: Office of Fissile Materials Disposition; Kimberly Prono, NA-25: Office of International Material Protection \& Cooperation; Elena Hushbeck, NA-242: International Nuclear Safeguards and Engagement Program; Aiste Ray, NA-256: Office of Second Line of Defense \& Megaports Initiative; Kristina Hatcher, NA-211: Office of North \& South American Threat Reduction; James Conner, NA-242: International Nuclear Safeguards and Engagement Program; Aaron Tatyrek, NA-213: Office of Former Soviet Union (FSU) \& Asian Threat Reduction; Jeremy Patterson, NA-242: International Nuclear Safeguards and Engagement Program; Maia Gemmill, NA-255: Office of National Infrastructure and Sustainability; H. Jessica Raber, NA-20: The Office of Defense Nuclear Nonproliferation; Stefan Melnick, NA-211: Office of North \& South American Threat Reduction; Lauren Lafaro, NA-242: Front Office of Nonproliferation and International Security; J. Clark Cully, NA-22: Nonproliferation Research \& Development; Jessica Drum, NA-242: International Nuclear Safeguards and Engagement Program; Scott Ravenhill, NA-213: Office of FSU \& Asian Threat Reduction; Jennifer Lacey, NA-212: Office of European \& African Threat Reduction; Justin Reed, NA-24: Office of Nonproliferation \& International Security; Richard Payne-Holmes, NA-242: Global Initiatives for Proliferation Prevention; Randy Howell, NA-21: Office of Global Threat Reduction; and Alexis Blanc, NA-243: Office of International Regimes \& Agreements.

Brief biographies on the Fellows of the Class of 2008 are provided in Appendix A. 


\section{Class of 2009}

\section{Recruitment Strategy}

Recruiting activities for the Class of 2009 began with strategy development in early 2008, and university outreach began in the spring.

Based on the 2008 results, the strategy continued to build upon the NGFP's three-pronged approach to recruitment: targeted, criteria, and associationbuilding. A review of 2007 recruitment efforts found that 10-15 key schools provided approximately $75 \%$ of the chosen NGFP Fellows. In 2008, the NGFP will again 'target' these schools and work to build lasting relationships with them. The success of smaller information sessions as opposed to career fairs will be built upon (except for certain situations, such as the ANS Student Conference). The primary methods of recruitment will engage PNNL university recruiters, NNSA colleagues, and current NGFP Fellows nearest to each university. The criteria from 2007 proved successful and will continue to be used; target schools must meet at least two of the four criteria. The NGFP will also continue to broaden and deepen linkages with associations, including the ANS, WIIS, the National Society of Black Engineers, and the Institute of Nuclear Materials Management.

To further increase the number and quality of technical candidates, the NGFP team leveraged PNNL technical staff to link with targeted technical programs. The Nuclear Engineering departments at University of California Berkeley, University of Michigan, Kansas State University, University of New Mexico, and Oregon State University all received technical presentations from a senior technical representative from PNNL. In addition, the NGFP participated in several targeted events that focused on technical candidates. In the spring timeframe, PNNL attended the ANS Student Conference, which had over 300 Nuclear Engineering students in attendance. 


\section{On the Horizon}

The year in progress promises to continue the trend in the program's improvements and growing mission impact. The Federal and PNNL Program Managers have made several efficiency improvements, produced excellent recruitment results, and made changes to continue to enhance the program experience for Fellows.

Highlights include:

- Improved Orientation experience for incoming Fellows

- Greater outreach in recruitment activities with associations

- Increased university partnerships

- Record-setting quantity and quality of applicants

- Excellent efficiency during Interview Week, involving well over 150 interviews

- Expanded class size

- Expeditious processing for security clearances at even faster rates

- Updated program mission and vision

- Official program documentation in a published Standard Operations and Procedures Manual.

The next Annual Report, for activities from June 2008 to June 2009, will provide all of these highlights and more, demonstrating the NGFP's continued commitment to excellence and support of the NNSA's mission. 


\section{Appendix A: Class of 2008 Fellows}

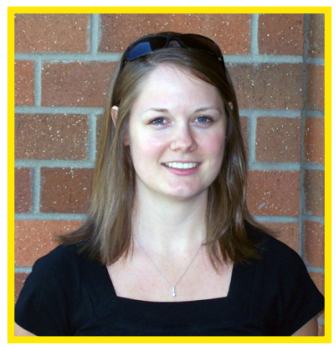

\section{Alexis Blanc, NA-243: Office of International Regimes \& Agreements}

Alexis Blanc graduated from George Washington University with an M.A. in Security Policy Studies. She also holds a B.A. from Washington State University with concentrations in Political Psychology, Middle East, National Security, and American Foreign Policy, as well as studies in Global Emphasis at the University of Wales. During the summer of 2007, Ms. Blanc worked as an Adjunct Research Assistant at the Institute for Defense Analysis in the Strategy, Forces, and Resources Division, where she created a model for assessing the historical trends of the proliferation of nuclear technology and analyzed the implications of those trends to draw lessons for future efforts in counter-proliferation. Later that same year, Ms. Blanc became a Policy Development Analyst for U.S. Citizenships and Immigration at the Department of Homeland Security.

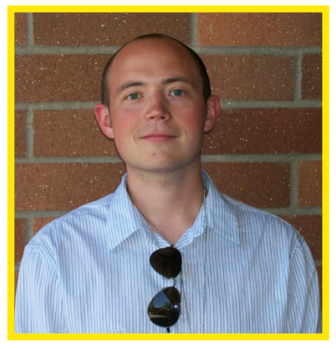

\section{James Conner, NA-242: International Nuclear Safeguards and Engagement Program}

James Conner is a graduate of American University's School of International Service with an M.A. in International Affairs. Her earned a B.A. in English Literature from the University of Denver and spent a summer during his graduate studies at the Korea University in Seoul, South Korea. Augmenting his education, Mr. Conner has spent more than three years in Seoul, South Korea, where he worked as English instructor at various Korean educational institutions as well as interned for the International Security Program at the Center for Strategic and International Studies.

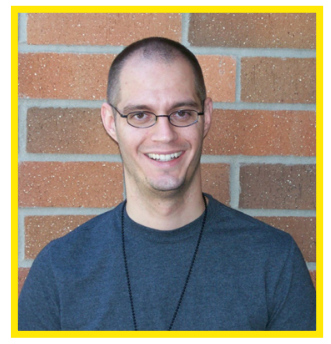

\section{J. Clark Cully, NA-22: Nonproliferation Research \& Development}

J. Clark Cully earned his M.S. and is currently a Ph.D. candidate in Physics from the University of Michigan, where he specialized in Experimental High-Energy Physics and had additional studies in Science Policy and Teaching. For his undergraduate studies, Mr. Cully had a double major in Math (B.A.) and Physics (B.S. with honors). Recently, Mr. Cully worked at Fermi National Laboratory, where he was a member of a large international team and collaborated with a diverse group to analyze problems, assign responsibilities, and reach consensus. Like many leaders in physics, he wishes to use his background to advance the field of global security. 


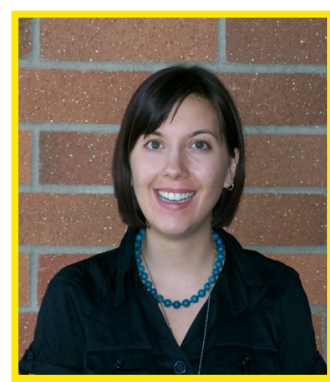

\section{Jessica Drum, NA-242: International Nuclear Safeguards and Engagement Program}

Jessica Drum is a graduate from the Monterey Institute of International Studies, where she earned an M.A. in International Policy Studies, specializing in Nonproliferation, and tracked and reviewed Egypt's Nuclear and Missile to develop communications material. Following receipt of her B.A. in Political Science from Colorado State University, Ms. Drum had studied at American University's Arabic Language Institute in Cairo, Egypt. During the summer of 2006, she attended the International Institute of Mediation and Conflict Resolution's Symposium in Nicosia, Cyprus. Ms. Drum has also completed an intensive Arabic course at Georgetown University.

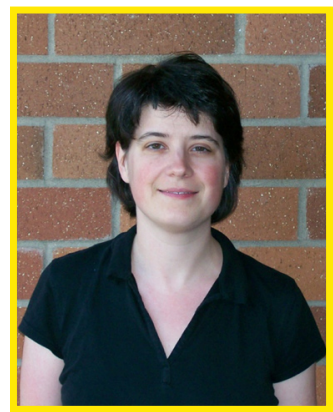

\section{Maia Gemmill, NA-255: Office of National Infrastructure and Sustainability}

Maia Gemmill earned her M.A. in International Relations with an emphasis on Russia/Eurasia Studies from the Johns Hopkins SAIS in May 2007. At Harvard University, Ms. Gemmill graduated magna cum laude with an A.B. in Social Studies, focusing on Russia and Eastern Europe. Augmenting her experience, she has a U.S. State Department Level 2 proficiency in Russian language ability with an emphasis on political and technical vocabulary. To contribute to U.S. foreign policy goals and global security as an NGFP Fellow, Ms. Gemmill will merge her academic training in Russian affairs and nonproliferation issues with her strong skills in managing large and diverse teams, overseeing a budget and a project schedule, and ensuring stakeholder satisfaction.

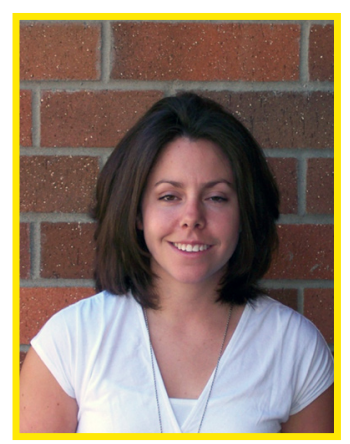

\section{Kristina Hatcher, NA-211: Office of North \& South American Threat Reduction}

Kristina Hatcher is a graduate of the University of Denver's Graduate School of International Studies with an M.A. in International Security and focus on Intelligence and the Middle East. As an undergraduate, Ms. Hatcher earned dual degrees from the University of Colorado-Boulder: a B.A. in International Affairs and a B.A. in International Spanish for the Professions. During that time, she studied abroad at the Universidad de Sevilla through the Center for

International Education and Exchange in Sevilla, Spain. During her graduate studies, Ms. Hatcher interned with the U.S. State Department, where she acquired a basic knowledge of arms control agreements and limitations treaties such as the Conventional Forces in Europe Treaty. 


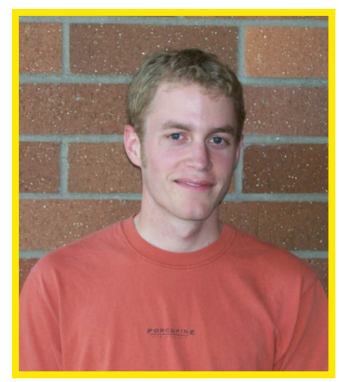

\section{Randy Howell, NA-21: Office of Global Threat Reduction}

Randy Howell earned his M.A. in International Studies from the University of Denver's Graduate School of International Studies. His areas of concentration were Security, Environmental Policy, and Communications, and his program included study abroad in the Latin American Politics Program in Costa Rica. Before earning his Master's degree, Mr. Howell earned a B.A. in Political Science from the University of Portland, where he completed an additional study abroad program in Salzburg, Austria. Mr. Howell has interned with the U.S. State Department Mission to International Organizations in Vienna, Austria. In addition, he spent an academic year as Fulbright English Language Teacher through the Technical Forestry School in Bruck an der Mur, Austria.

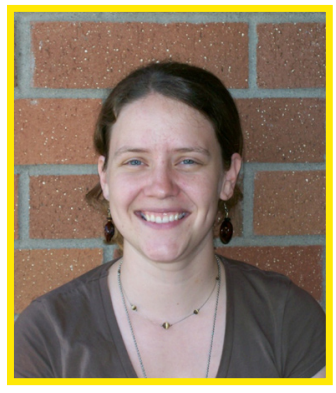

\section{Elena Hushbeck, NA-242: International Nuclear Safeguards and Engagement Program}

Elena Hushbeck is a graduate of the Monterey Institute of International Studies with an M.A. in International Policy Studies and Certificate in Nonproliferation Studies. Ms. Hushbeck earned her B.A. summa cum laude in Political Science with a concentration in International Relations from the University of New Mexico. During her undergraduate studies, she attended mediation training, where she learned the philosophies and techniques of third-party intervention and alternative dispute resolution. Ms. Hushbeck has also been an intern for the United Nations Office of Disarmament Affairs in New York.

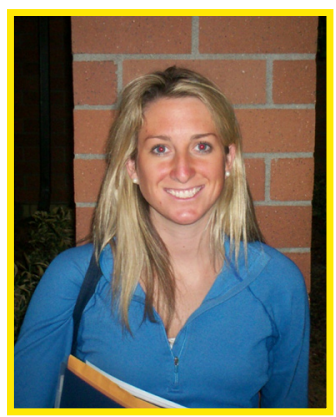

\section{Jennifer Lacey, NA-212: Office of European \& African Threat Reduction}

Jennifer Lacey is a M.A. International Affairs candidate at the George Washington University and has spent one year at the Monterey Institute for International Studies. Immediately after earning a B.A. in International Studies and Spanish at Denison University in Ohio, she obtained a certificate with honors from the McIntire Business Institute at the University of Virginia. Ms. Lacey has served as an intern for the

Committee on Senate Foreign Relations in Washington, D.C. She has been a Research Associate for FirstWatch International in Monterey, California, and has written for several publications on nonproliferation issues. Most recently, she was Nuclear Analyst for the Partnership for Global Security in Washington, D.C. 


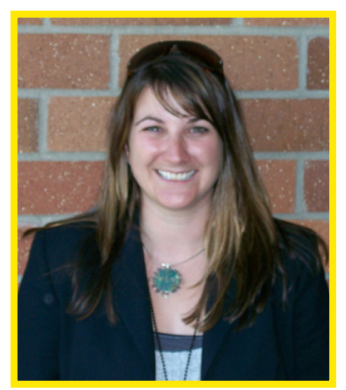

\section{Lauren Lafaro, NA-242: Front Office of Nonproliferation and International Security}

Lauren Lafaro earned her M.A. from the University of Washington's Russian, East European, and Central Asian Studies program in International Studies with a focus on Political Science and Nonproliferation Studies. For her undergraduate studies, Ms. Lafaro earned a dual degree with a B.A. in International Government and a B.A. with honors in Russian Studies from Darmouth College. Through the American Council for International Education, she studied in Tajikistan for intensive study of the Uzbek language. In addition, Ms. Lafaro attended the University of St. Petersburg for extensive coursework in Russian language, literature, and culture.

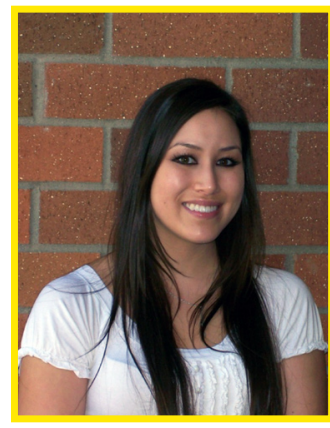

\section{Kristen Lau, NA-242: International Nuclear Safeguards and Engagement Program}

Kristen Lau earned an M.A. from the University of Washington's Henry M. Jackson School of International Studies, with foci in Security Studies and Information Management, and earned a certificate in Global Trade, Transportation, and Logistics. Ms. Lau also earned her B.A. from the University of Washington's Jackson School, in the Foreign Policy, Diplomacy, Peace, and Security track. During her academic years, she was a Teaching Assistant for a course on International Law and Arms Control, an Assistant Researcher for the British American Security Information Council in London, and a Graduate Assistant for the Institute for National Security Education and Research program. Ms. Lau is a member of the Arms Control Association and the Institute for Nuclear Materials and Management.

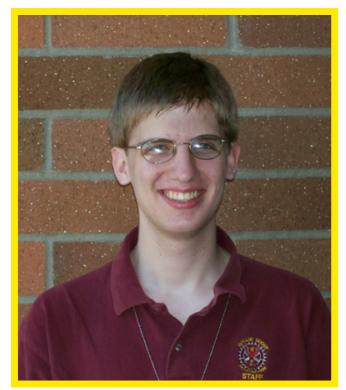

\section{Stefan Melnick, NA-211: Office of North \& South American Threat Reduction}

Stefan Melnick is a candidate for an M.S. in Radiation Health Physics from Oregon State University. His primary areas of concentration are radiation protection, nuclear nonproliferation, radiation shielding and detection, and how the proper applications of these areas can be used to stem the flow of unauthorized nuclear materials. Mr. Melnick's

undergraduate studies earned dual B.S. degrees in Engineering Physics and Nuclear Engineering from Rensselaer Polytechnic Institute in Troy, New York, during which summers he worked for the New York State Department of Transportation as a Construction Inspector. 


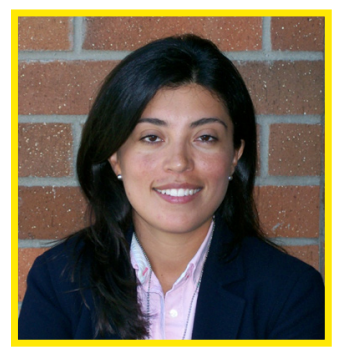

\section{Kathia Niewiadomski, NA-26: Office of Fissile Materials Disposition}

Kathia Niewiadomski earned an M.A. in International Security from the University of Denver's Graduate School of International Studies, with a specialization in Strategy and Arms Control. She earned a B.A. magna cum laude from Southern Connecticut State University with a major in Political Science. Ms. Niewiadomski has experience as a Staff Analyst on nonproliferation issues for FirstWatch International in Monterey, California; an Intern Research Assistant for the Center for Strategic and International Studies in Washington, D.C.; and an Analyst for the Defense Capabilities Management Team at the Government Accountability Office. Ms. Niewiadomski was also a Nuclear Scholar for the 2007-2008 Nuclear Scholars Initiative at the Center for Strategic and International Studies in Washington, D.C., and expects that research to result in publication.

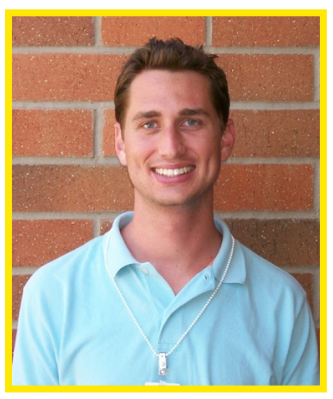

\section{Jeremy Patterson, NA-242: International Nuclear Safeguards and Engagement Program}

Attending American University in Washington, D.C., Jeremy Patterson earned his M.A. with a primary focus in International Politics/International Security and secondary focus in International Peace and Conflict Resolution. Mr. Patterson earned his B.A. in Psychology from Washington University in St. Louis, Missouri, where he also gained varied experience as a Consultant in the Center for Engineering Computing and Research Assistant for the University's School of Medicine. Concurrent with his graduate studies, Mr. Patterson was on Federal Work Study for the Graduate Admissions Office at the School of International Service at American University. He anticipates being certified by the U.S. Department of Agriculture Graduate Language School at the intermediate level in Chinese.

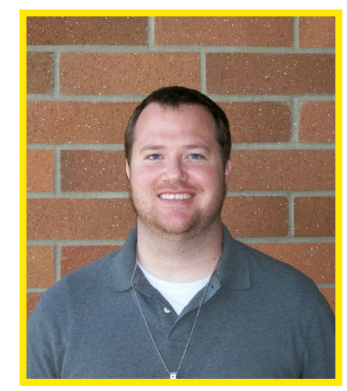

\section{Richard Payne-Holmes, NA-242: Global Initiatives for Proliferation Prevention}

Richard Payne-Holmes earned a joint M.A. in Russian and Eastern European Studies and M.P.A. in Public Affairs from Indiana University-Bloomington. Similarly, Mr. PayneHolmes earned a double major from Brigham Young University: a B.A. in History with a focus on the Soviet variety and a B.A. in Russian. Mr. Payne-Holmes has studied abroad extensively: in the Ukraine through the Ivan Franko National University; and in Belgium, France, Germany, and Poland through the Indiana University European Union Center of Excellence. He has served as both the Vice President and President of the Indiana University Ukrainian Studies Organization for the advancing the awareness of Ukrainian culture. 


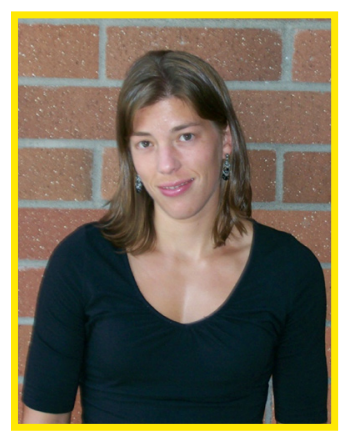

\section{Kimberly Prono, NA-25: Office of International Material Protection \& Cooperation}

Kimberly Prono is an M.A. candidate in International Affairs with a concentration in U.S. Foreign Policy at American University in Washington, D.C. During her undergraduate career at Northwestern University, Ms. Prono earned her B.A. in Political Science as well as a Certificate in Government during a year abroad at the London School of Economics and Political Science. Ms. Prono's vast work experience includes the Russian Nonproliferation Program at Los Alamos National Laboratory, where she read research proposals by Former Soviet Union (FSU) nuclear scientists and identified appropriate reviewers in American academia and industry.

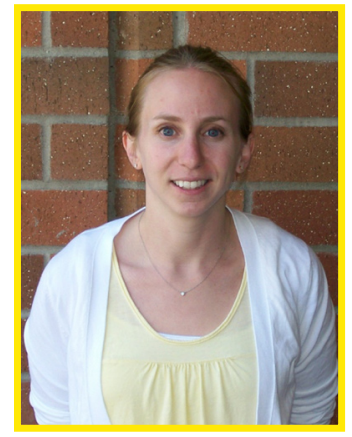

\section{H. Jessica Raber, NA-20: The Office of Defense Nuclear Nonproliferation}

H. Jessica Raber is a graduate in the Master of Public Administration program in the interdisciplinary International Science and Technology Policy and Nuclear Nonproliferation at the University of Washington. She earned her B.A. in Communication from Stanford University, where she also served as Assistant Sports Information Director for Stanford's media relations. She pursued her M.P.A. to develop skills and knowledge in policy analysis to complement her extensive communications experience at the University of Washington and the U.S. Naval Academy, which turned into a concentration in the study of nuclear nonproliferation and science policy. Ms. Raber interned at the U.S. Nuclear Regulatory Commission in Rockville, Maryland, during the summer of 2007.

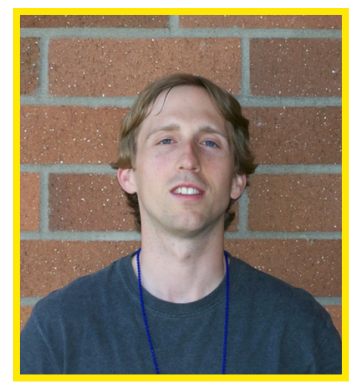

\section{Scott Ravenhill, NA-213: Office of FSU \& Asian Threat Reduction}

Scott Ravenhill earned his M.A. in International Policy Studies with a specialization in Nonproliferation Studies from the Monterey Institute of International Studies. Mr. Ravenhill also attended the University of Missouri, where he earned a double major with a B.A. in International Studies, Spanish Concentration, and a B.S. in International Business, Finance Concentration. After his undergraduate studies, he served as English instructor in both Busan, South Korea and Osaka, Japan. Most recently, Mr. Ravenhill served as a summer 2007 intern at the U.S. State Department in Osaka, Japan, 


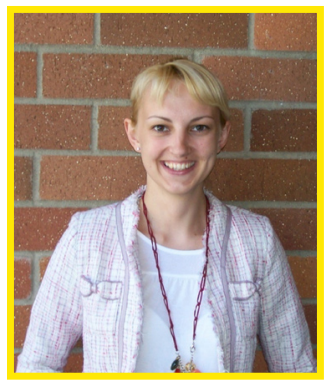

\section{Aiste Ray, NA-256: Office of Second Line of Defense \& Megaports Initiative}

Aiste Ray graduated with an M.A. in Political Science with a specialization in International Politics and Comparative Governments from George Mason University in Fairfax, Virginia. Ms. Ray is a U.S. Army veteran, deployed during Operation Iraqi Freedom. After her military service, Ms. Ray graduated from George Mason University with a B.A. magna cum laude in Global Affairs with a concentration in Global Diplomacy and Governance and minors in Information Technology and Conflict Analysis and Resolution. She has been a Lithuanian school teacher for several years, served as a Congressional Intern, and has been Office Manager for the Truman National Security Project/Truman Security Forum.

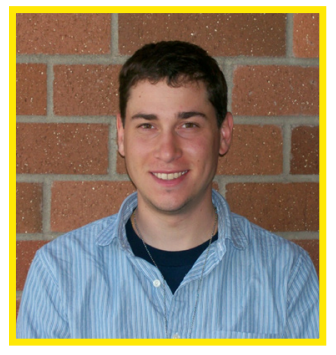

\section{Justin Reed, NA-24: Office of Nonproliferation \& International Security}

In 2008, Justin Reed earned his M.A. in International Security from Georgetown University's School of Foreign Service Security Studies program. He earned a B.A. in History and Rhetoric with a Creative Writing focus from the University of Illinois Champaign-Urbana, where he was the recipient of a Global Interactions undergraduate scholarship and took a variety of history, military, and nuclear-related courses. He has interned for both the Chicago Council on Foreign Relations and the Arms Control Association. Most recently, Mr. Reed served as Nuclear Nonproliferation Analyst at the Partnership for Global Security. He has also recently been admitted as a member of the Center for Strategic and International Studies' Project on Nuclear Issues.

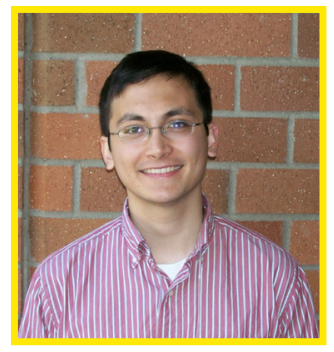

\section{Aaron Tatyrek, NA-213: Office of FSU \& Asian Threat Reduction}

Aaron Tatyrek is an M.A. graduate of the Henry M. Jackson School for International Studies from the University of Washington, focused on U.S./Russian relations and international security policy with emphasis on weapons of mass destruction proliferation. Mr. Tatyrek graduated magna cum laude from Texas A\&M University with a B.A. in Political Science and Russian. He also received a Certificate in Russian Language Studies from the Moscow Technical Institute of Languages and Informatics in Moscow, Russia. Mr. Tatyrek has served in a number of leadership and volunteer activities, and his work experience has ranged from being a Senatorial intern to a physician's clerical assistant to a teaching assistant at the University of Washington. 

Phyllis B. Byrd, Federal Program Manager

PNNL-18365

NNSA, Office of Defense Nuclear Nonproliferation

Office of International Operations

phyllis.byrd@nnsa.doe.gov

Jana Fankhauser, Contractor Program Manager

Nonproliferation Graduate Program

Pacific Northwest National Laboratory

(206) 528-3264

ngp@pnl.gov

Visit us at http:Ilngp.pnl.gov.

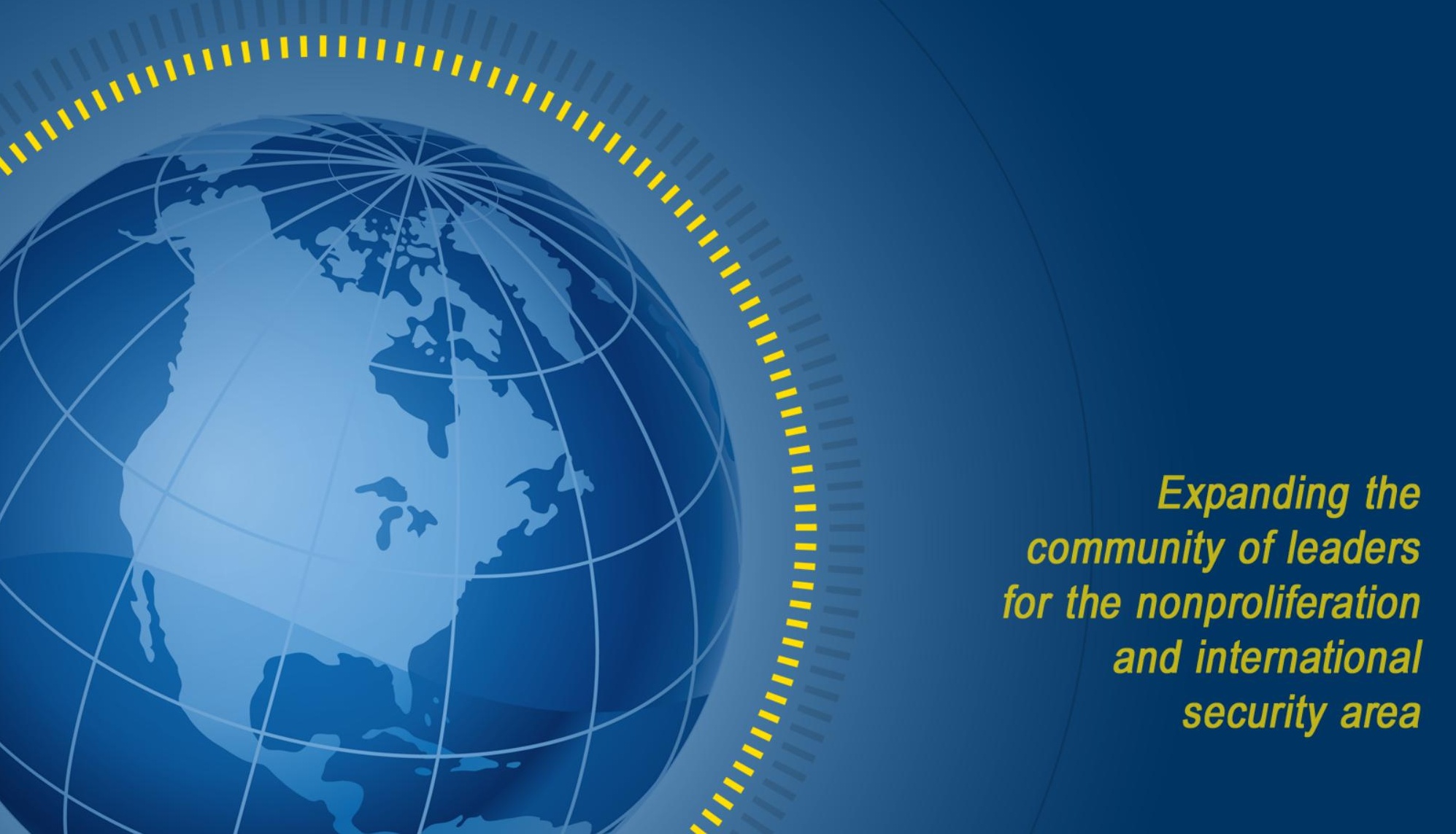

